\title{
To Study the Factors Affecting the Job Satisfaction and Level of Job Satisfaction at Baswara Garments Ltd
}

\author{
Dr. Kedar Shukla ${ }^{1 *}$, Ashish Singh ${ }^{2}$
}

\section{ABSTRACT}

'Job satisfaction' describes how content an individual is with his or her job. It is a relatively recent term since in previous centuries the jobs available to a particular person were often predetermined by the occupation of that person's parent. There are a variety of factors that can influence a person's level of job satisfaction. Some of these factors include the level of pay and benefits, the perceived fairness of the promotion system within a company, the quality of the working conditions, leadership, supervisions and social relationships, the job itself (the variety of tasks involved, the interest and challenge the job generates, and the clarity of the job description/requirements). The happier people are within their job, the more satisfied they are said to be.

Job satisfaction is often misunderstood same as motivation, although it is clearly linked. Job design aims to enhance job satisfaction and performance methods include job rotation, job enlargement and job enrichment. Other influences on satisfaction include the management style and culture, employee involvement, empowerment and autonomous workgroups. Job satisfaction is a very important attribute which is frequently measured by organizations.

In the present research paper authors have tried to conduct a study on the factors that affect, on employees job satisfaction, of a particular industry and a company. Study also attempt to measure the job satisfaction levels on the various selected factor. For research study M/s Banswara Garments (A Unit of Banswara Syntex Ltd),Daman has been chosen, The rational for selecting the same is , the company has approximately 950 employees, and HR department observed that the attrition rate of workers have been increasing since last 3 years. Company wanted to conduct a research on job satisfaction which have never been done before as a part process of worker behaviour which increasing attrition rate.

Keywords: Job Satisfaction; Job Analysis ; Employee Satisfaction ; Human Resource Department.

\footnotetext{
${ }^{1}$ Professor of Marketing and Strategy and Head of the Department at ROFEL-MBA College at Vapi, Gujarat, India

${ }^{2}$ MBA-HR and at present working at head HR at Aarya Hospitals Vapi, India

*Responding Author

(C) 2016 I K Shukla, A Singh; licensee IJIP. This is an Open Access Research distributed under the terms of the Creative Commons Attribution License (http://creativecommons.org/licenses/by/2.0), which permits unrestricted use, distribution, and reproduction in any Medium, provided the original work is properly cited.
} 


\section{To Study the Factors Affecting the Job Satisfaction and Level of Job Satisfaction at Baswara Garments Ltd}

Job satisfaction describes how content an individual is with his or her job. It is a relatively recent term since in previous centuries the jobs available to a particular person were often predetermined by the occupation of that person's parent. There are a variety of factors that can influence a person's level of job satisfaction. Some of these factors include the level of pay and benefits, the perceived fairness of the promotion system within a company, the quality of the working conditions, leadership, supervisions and social relationships, the job itself (the variety of tasks involved, the interest and challenge the job generates, and the clarity of the job description/requirements). The happier people are within their job, the more satisfied they are said to be.

Job satisfaction is not the same as motivation, although it is clearly linked. Job design aims to enhance job satisfaction and performance methods include job rotation, job enlargement and job enrichment. Other influences on satisfaction include the management style and culture, employee involvement, empowerment and autonomous workgroups. Job satisfaction is a very important attribute which is frequently measured by organizations.

The most common way of measurement is the use of rating scales where employees report their reactions to their jobs. Questions relate to relate of pay, work responsibilities, variety of tasks, promotional opportunities the work itself and co-workers. Some questioners ask yes or no questions while others ask to rate satisfaction on 1 - 5 scale where 1 represents "Strongly Dissatisfied" and 5 represents "Strongly satisfied".

People management is an important aspect of organisational processes. This emanated from the recognition that the human resources of an organisation and the organisation itself are synonymous. A well-managed business organisation normally considers the average workers as the primary source of productivity gains. These organisations consider workers rather than capital as the core foundation of the business and contributors to firm development.

\section{Introduction of the company}

Banswara Garment (BG, hereafter) is a vertically integrated textile mill manufacturing manmade synthetic blended Yarn, wool and wool mixed yarn, all type of Fabrics, Jacquard Furnishing Fabrics, besides production of Readymade Garments and Made-up's. It has also production of Technical Fabric. Initially it was a spinning mill with 12500 spindles. As the journey continued the Company completed expansion, diversification and modernization plans. Over the last 3 decades, Company besides increasing the Spinning capacity to 143240 spindles, started production of Fabric from 1993, Readymade Garments, Made-up's and Worsted Spinning. The Company also entered into Joint Venture with French Company Carreman in 2006 for products of women used Lycra manufacturer and with French company Treves SA for Automotive Textiles in 2012. The Company is one of the largest single mill setup producing spun fibre-dyed yarns in Asia and $90 \%$ of the production is fibre dyed. It also started the 


\section{To Study the Factors Affecting the Job Satisfaction and Level of Job Satisfaction at Baswara Garments Ltd}

production of laminated \& other type of technical fabrics for high altitude weather \& also suitable for sportswear etc. . It is also supplying all wool \& P/W fabrics world's most reputed brands all around the globe. Commenced generation of power on 2nd unit of Thermal Power Plant of 15 MW capacity and has a captive power of $30 \mathrm{MW}$. The company embarked on cloth weaving activity in the year 1993 with brand name of BANTEX. The company manufacturing fabrics with Lycra purchased from international brand, Dupont. Banswara Garment Limited exports its products to more than 50 countries including US, UK, Canada, Spain, Germany, Italy, France, Philippines, Turkey and GCC countries. In the year 2005, Banswara Textile Mills Ltd., an associate firm engaged in fabric finishing activity, amalgamated with the company. HR Policies of BG, provides two types of rewards to the employees, they are monitory and nonmonitory. The company provide many fringe benefits to the employees like trip facility, bonus, compensation, loan facility etc.

\section{RESEARCH PROBLEM AND RESEARCH METHODOLOGY}

\section{(a) Research Problem :}

Banswara Garments (A Unit of Banswara Syntex Ltd),Daman has 950 employees and HR department observed that the attrition rate of workers have been increasing since last three years They wanted to conduct a research on job satisfaction and factors affecting their satisfaction level, which have never been done before as a part process of worker behaviour which increasing attrition rate.

\section{(b) Research Objectives:}

$>$ To identify the factors affecting job satisfaction.

$>$ To study the satisfaction level of workers in Banswara Garments Ltd.

$>$ To measure the impact of each factor on overall job satisfaction of workers.

$>$ To measure the impact of demographic factor on overall job satisfaction.

\section{(c) Types of Data and Sampling:}

Descriptive research methodology has been used and both primary and secondary data have been collected. Primary data were collected through interaction with personal interview. Secondary data were collected from the prospectus of the firm and website of the company. Non-Probability samples (convenient sampling) method has been used for the research. Sample size of 200 samples was selected for the primary data sampling as universe is of 950 employees which is nearly about $20 \%$ as recommended in the research scales of job satisfaction measurements.

(d) Hypothesis and Hypothesis Testing :

Following Hypothesis have been made and tested to achieve objectives in the sound manner.

H0: Satisfaction level of working condition is independent of demographic factors (Age , Gender, Category, Income level).

H1: Satisfaction level of working condition is not independent of demographic factors (Age , Gender, Category , Income level). 


\section{To Study the Factors Affecting the Job Satisfaction and Level of Job Satisfaction at Baswara Garments Ltd}

H0: Satisfaction level of Pay is independent of demographic factors (Age , Gender , Category, Income level).

H1: Satisfaction level of Pay in not independent of demographic factors (Age , Gender , Category, Income level).

H0: Satisfaction level of Promotion is independent of demographic factors (Age , Gender , Category , Income level).

H1: Satisfaction level of Promotion is not independent of demographic factors (Age , Gender, Category , Income level).

H0: Satisfaction level of Supervision is independent of demographic factors (Age , Gender, Category, Income level).

H1: Satisfaction level of Supervision is not independent of demographic factors (Age , Gender, Category , Income level).

H0: Satisfaction level of Overall satisfaction is independent of demographic factors (Age , Gender, Category, Income level).

H1: Satisfaction level of Overall satisfaction is not independent of demographic factors (Age , Gender , Category , Income level).

H0: Satisfaction level of workers have not significant impact on overall satisfaction.

H1: Satisfaction level of workers have significant impact on overall satisfaction.

\section{Hypothesis Testing}

Chi-square test of independence has been used to analyze the frequencies of two variables with multiple categories to determine whether the two variables are independent. Regression analysis has been used to construct a mathematical model or function to predict or determine one variable by another variable or other variables.

\section{LITERATURE REVIEW}

I. Exhaustive literature was reviewed to understand theoretical concept of job satisfaction, to know the various factors affecting the employees job satisfaction and to understand correlation between demographic factors and job satisfaction. To state few of them , Parvin $\mathrm{M}$ and et all (2011) in their study on the pharmaceutical sector, they evaluated that job satisfaction of employees in different pharmaceutical companies are related to their work experience, age, and sex differences. The result shows that salary, efficiency in work, fringe supervision, and co-worker relation are the most important factors contributing to job satisfaction. Kumari G. and Pandey M stated that, Job satisfaction describes how content an individual is with his or her job. The happier people are within their job, the more satisfied they are said to be. In their paper surveys both the sectors private and government to understand the difference of factor affecting job satisfaction in both the sectors. S. M. Ikhtiar Alam , Mostafa Kamal reveals that, Job satisfaction is an attitude that reflects the extent to which an individual is gratified by or fulfilled in his/her job. It is an affective or emotional response toward various facets of one's job. This 


\section{To Study the Factors Affecting the Job Satisfaction and Level of Job Satisfaction at Baswara Garments Ltd}

meaning of job satisfaction implies that job satisfaction is not a unitary concept. Rather a person can be relatively satisfied with one aspect of his or her job and dissatisfied with one or more other aspects. Thus, we can differentiate at least two aspects of job satisfaction - facet satisfaction and overall satisfaction. Facet satisfaction is the tendency for an employee to be more or less satisfied with various facets of his or her job.

\section{DATA ANALYSIS AND INTERPRETATION}

(a) Data Interpretation Following observation has been found from the data collection.

- At present at BGL has 12 hours of working shift, on asking about the satisfaction with respect to the working hours $72 \%$ of the respondents are satisfied with the working hours and $30 \%$ of the respondent are not satisfied with the working hours.

- With respect to working condition it has been found that $74 \%$ of the respondents believes that BGL has a good working conditions, $12 \%$ of the respondent are neutral and $14 \%$ of the respondent are not satisfied with the working conditions.

- Regarding risk of accident $88 \%$ employees believes that the job has low risk and better risk management systems , 6\% employees turned neutral and 6\% employees feels that it is unsafe with high accident risk.

- With respect to infrastructure it has been found that $74 \%$ employees believed to have adequate infrastructure during the job while $12 \%$ employees are not happy with the infrastructure support on job.

- With respect to performance reward and promotions 68\% employees are found satisfied and 32\% employees are not satisfied with rewards mechanism. $70 \%$ employees feels that the organization takes in to account seniority in promotion policy and the same is desirable while $32 \%$ employees are not agreed with the consider it undesirable.

- Provision of leaves are also one among the key factor of satisfaction, 70\% employees are satisfied with current leave rules and policy of the company however more than $25 \%$ employees are dissatisfied, while rest are neutral about the same.

- Perks and other variable benefits almost 68\% employees are satisfied with company's current policy of medical insurance, bonus and other facilities provided by company around 6\% employees are neutral and rest around 26\% employees are dissatisfied on that account.

- It is being recorded that around 58\% employees are satisfied with the policy of training and development however $42 \%$ employees are neutral or dissatisfied with the current policy of skills development , trainings etc.

- With respect to over all satisfaction it is interpreted that $50 \%$ of the respondent are strongly satisfied, $18 \%$ of the respondent are moderately satisfied, $14 \%$ of the respondent are neutral , while $18 \%$ of the respondent are not satisfied. 


\section{To Study the Factors Affecting the Job Satisfaction and Level of Job Satisfaction at Baswara Garments Ltd}

\section{(b) Hypothesis testing and measuring the impact of each factor on job satisfaction}

To understand the various factors affecting and measure it's impact on job satisfaction, data were collected through the questionnaire. Major factors identified from the literature review have been as Working conditions, Pay and related policies, Skills and Development, Promotion and supervision etc have been listed out . Employees perception regarding above factors were noted on a five point scale through the structured questionnaire. In the present research to test the co.relation with the demographic factors like age, gender, income level and grade on the above factors five hypothesis were constructed and the same has been tested on Chi-squre test. Employees perception towards over all job satisfaction in the company have also been recorded and tested via hypothesis.

The result of respondents record and results as well as interpretations through chi-square correlations have been tabulated in Table 1 to Table 7 as listed below.

\section{Hypothesis -1}

H0: Satisfaction level of working condition is independent of demographic factors (Age , Gender , Category , Income level).

H1: Satisfaction level of working condition is not independent of demographic factors (Age , Gender, Category , Income level).

\section{Table -1 Pearson Chi -Square Test result and interpretation For Hypothesis -1}

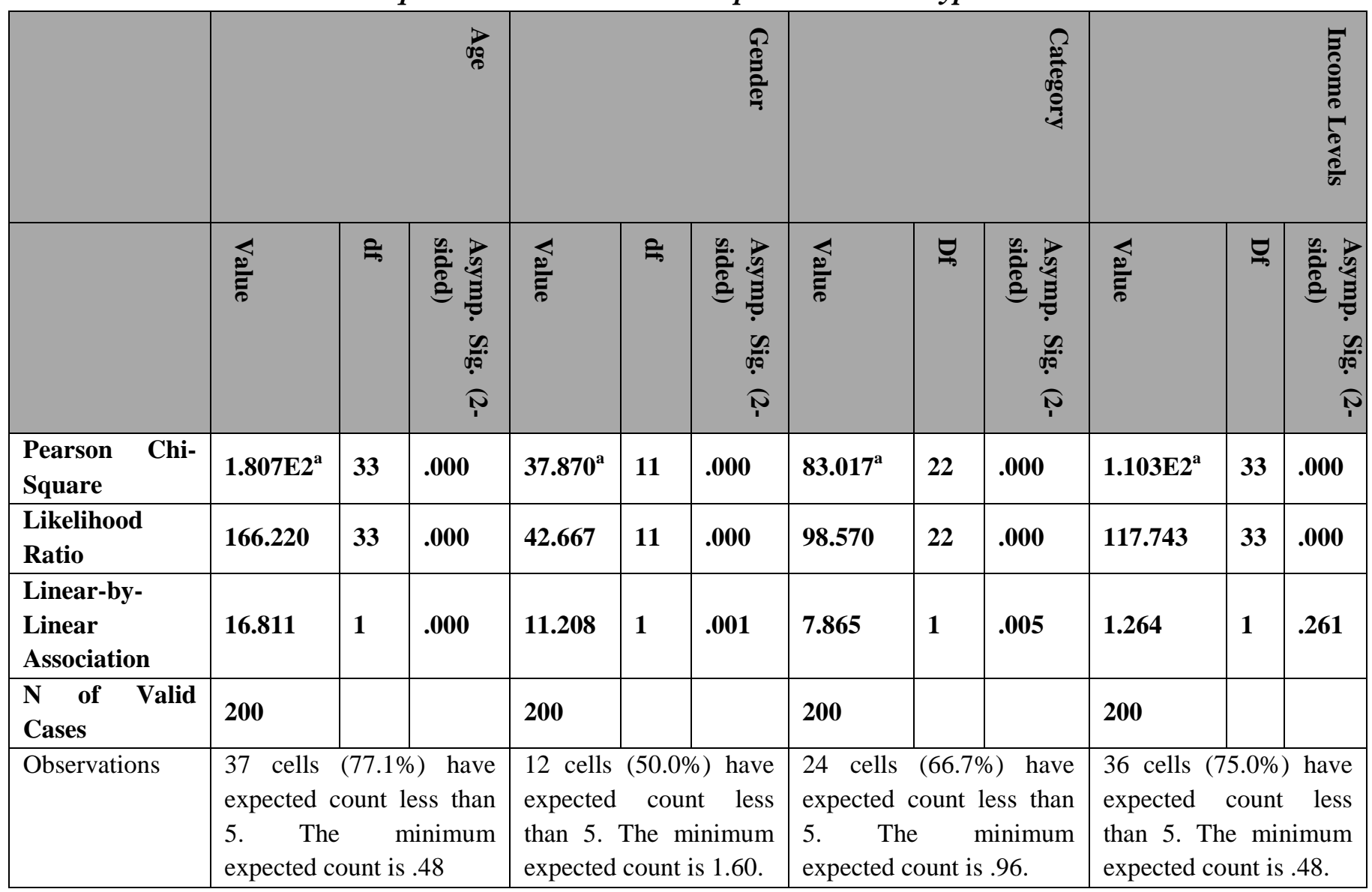




\section{To Study the Factors Affecting the Job Satisfaction and Level of Job Satisfaction at Baswara Garments Ltd}

\begin{tabular}{|c|c|c|c|c|}
\hline Interpreations & $\begin{array}{l}\text { From chi-square test } p \\
\text { value is }<0.05 \text { so it } \\
\text { rejects the null hypothesis } \\
\text { H0.and it accepts the } \\
\text { alternative hypothesis } \\
\text { H1. }\end{array}$ & $\begin{array}{l}\text { From chi-square test } \mathrm{p} \\
\text { value is }<0.05 \text { rejects } \\
\text { the null hypothesis H0. } \\
\text { and it accepts the } \\
\text { alternative hypothesis } \\
\text { H1. }\end{array}$ & $\begin{array}{l}\text { From chi-square test } p \\
\text { value is }<0.05 \text { rejects the } \\
\text { null hypothesis H0. } \\
\text { and it accepts the } \\
\text { alternative hypothesis } \\
\text { H1. }\end{array}$ & $\begin{array}{l}\text { Interpretation: From } \\
\text { chi-square test } \mathrm{p} \text { value } \\
\text { is < } 0.05 \text { rejects the } \\
\text { null hypothesis H0. } \\
\text { and it accepts the } \\
\text { alternative hypothesis } \\
\text { H1. }\end{array}$ \\
\hline
\end{tabular}

\section{Hypothesis -2}

H0: Satisfaction level of Pay is independent of demographic factors (Age , Gender , Category , Income level).

H1: Satisfaction level of Pay is not independent of demographic factors (Age , Gender , Category, Income level).

\section{Table -2 Pearson Chi -Square Test result and interpretation For Hypothesis -2}

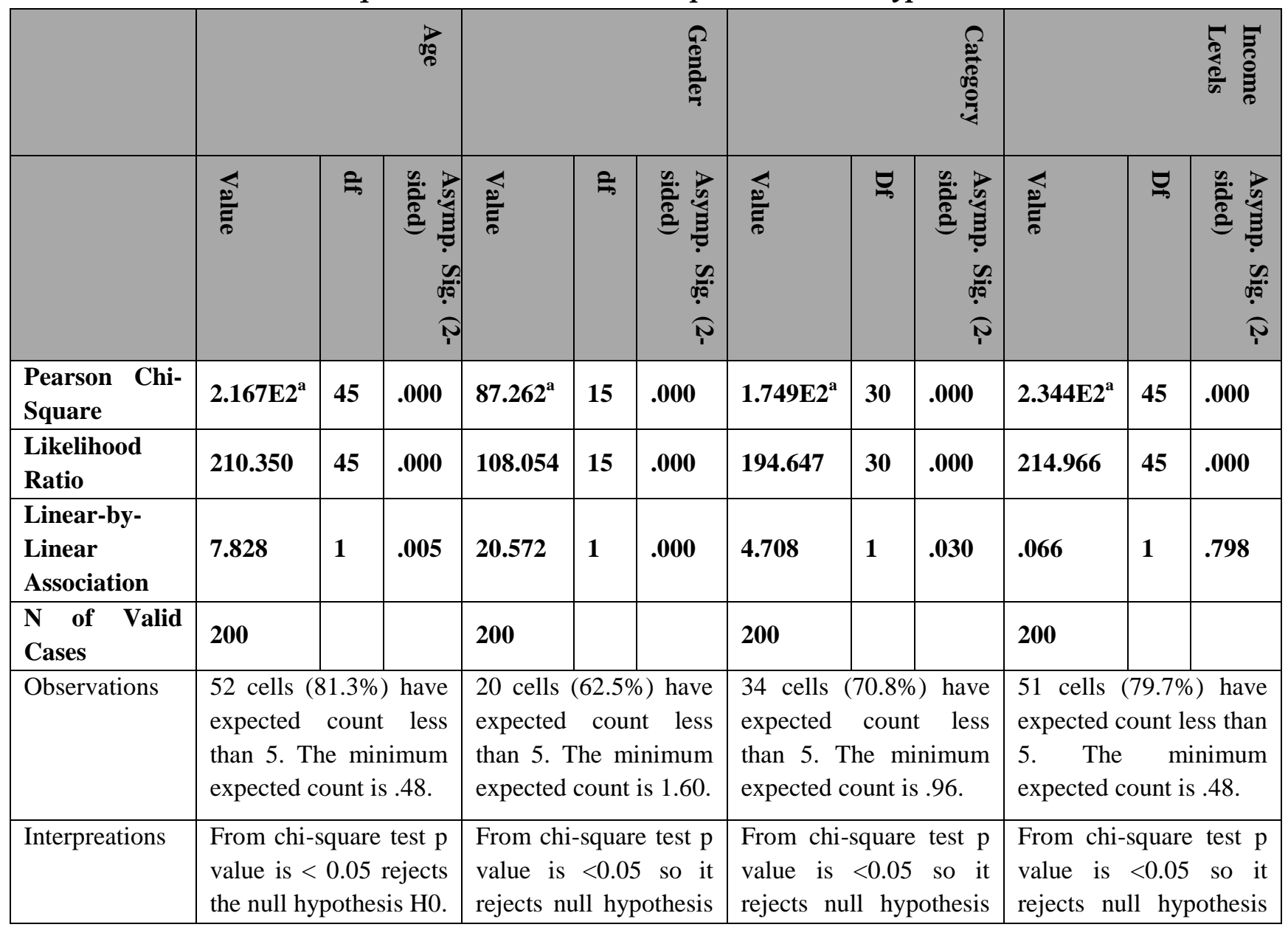




\section{To Study the Factors Affecting the Job Satisfaction and Level of Job Satisfaction at Baswara Garments Ltd}

\begin{tabular}{|l|l|l|l|l|}
\hline & $\begin{array}{l}\text { and it accepts the } \\
\text { alternative hypothesis } \\
\text { H1. }\end{array}$ & $\begin{array}{l}\text { H0. and it accepts the } \\
\text { alternative hypothesis } \\
\text { H1. }\end{array}$ & $\begin{array}{l}\text { H0. } \\
\text { and it accepts the } \\
\text { alternative hypothesis } \\
\text { H1. }\end{array}$ & $\begin{array}{l}\text { H0. } \\
\text { and it accepts the } \\
\text { alternative hypothesis } \\
\text { H1. }\end{array}$ \\
\hline
\end{tabular}

\section{Hypothesis -3}

H0: Satisfaction level of Promotion is independent of demographic factors (Age , Gender , Category , Income level).

H1: Satisfaction level of Promotion is not independent of demographic factors (Age , Gender , Category , Income level).

Table -3 Pearson Chi -Square Test result and interpretation For Hypothesis -3

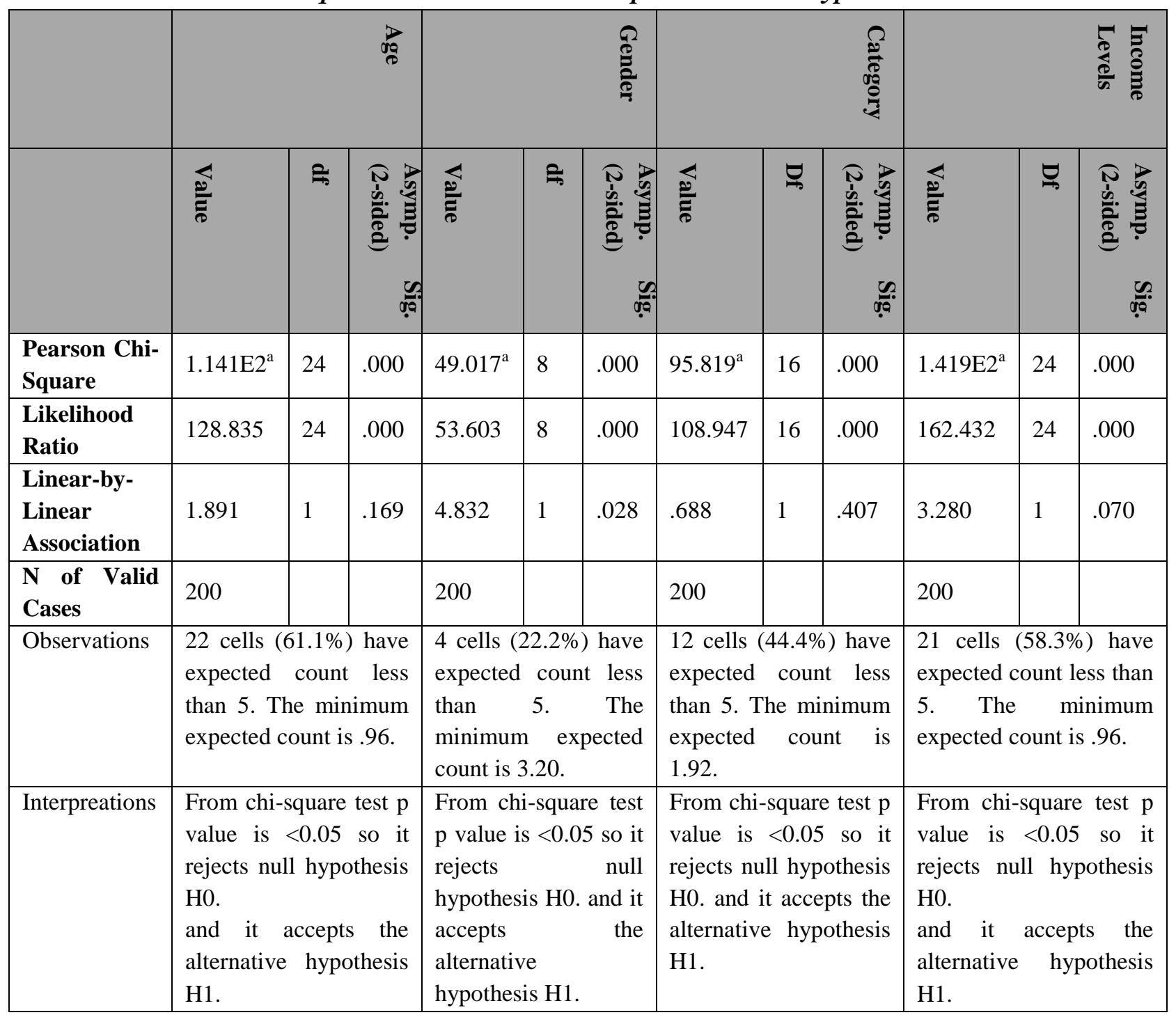




\section{To Study the Factors Affecting the Job Satisfaction and Level of Job Satisfaction at Baswara Garments Ltd}

\section{Hypothesis -4}

H0: Satisfaction level of Supervision is independent of demographic factors (Age , Gender , Category, Income level).

H1: Satisfaction level of Supervision is not independent of demographic factors (Age , Gender , Category, Income level).

\section{Table -4 Pearson Chi -Square Test result and interpretation For Hypothesis -4}

\begin{tabular}{|c|c|c|c|c|c|c|c|c|c|c|c|c|}
\hline & & & $\underset{0}{\overrightarrow{0}}$ & & & 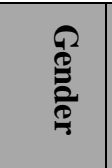 & & & 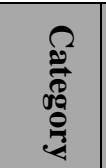 & & & 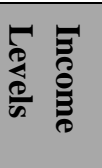 \\
\hline & 总 & ई & 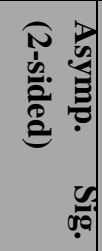 & 音 & $\nRightarrow$ & 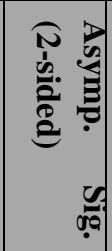 & 冚 & $\underset{\sim}{\ominus}$ & 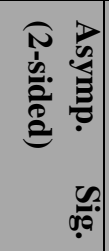 & 总 & $\underset{\rightarrow}{\ominus}$ & 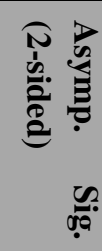 \\
\hline $\begin{array}{l}\text { Pearson Chi- } \\
\text { Square }\end{array}$ & $1.914 \mathrm{E} 2^{\mathrm{a}}$ & 36 & .000 & $91.746^{\mathrm{a}}$ & 12 & .000 & $1.803 \mathrm{E} 2^{\mathrm{a}}$ & 24 & .000 & $2.429 \mathrm{E} 2^{\mathrm{a}}$ & 36 & .000 \\
\hline $\begin{array}{l}\text { Likelihood } \\
\text { Ratio }\end{array}$ & 193.397 & 36 & .000 & 113.098 & 12 & .000 & 193.052 & 24 & .000 & 230.452 & 36 & .000 \\
\hline $\begin{array}{l}\text { Linear-by- } \\
\text { Linear } \\
\text { Association }\end{array}$ & 5.434 & 1 & .020 & 29.468 & 1 & .000 & 13.569 & 1 & .000 & 6.071 & 1 & .014 \\
\hline $\begin{array}{l}\mathbf{N} \text { of } \text { Valid } \\
\text { Cases }\end{array}$ & 200 & & & 200 & & & 200 & & & 200 & & \\
\hline Observations & $\begin{array}{l}40 \text { cells ( } \\
\text { expected } \\
\text { than } 5 . \mathrm{Tl} \\
\text { expected }\end{array}$ & $\begin{array}{l}6.9 \% \\
\text { cout } \\
\text { le m } \\
\text { ount }\end{array}$ & 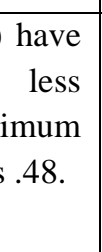 & $\begin{array}{l}11 \text { cell } \\
\text { have exp } \\
\text { less tha } \\
\text { minimum } \\
\text { count is } 1\end{array}$ & 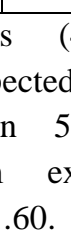 & $\begin{array}{r}2.3 \%) \\
\text { count } \\
\text { The } \\
\text { pected }\end{array}$ & $\begin{array}{l}26 \text { cells }( \\
\text { expected } \\
\text { than } 5 . \mathrm{Tl} \\
\text { expected c }\end{array}$ & $\begin{array}{l}56.7 \% \\
\text { coun } \\
\text { he mi } \\
\text { ount }\end{array}$ & 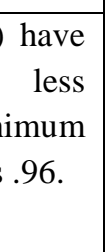 & $\begin{array}{l}38 \text { cells } \\
\text { expected } \\
\text { than } 5 . \mathrm{T} \\
\text { expected }\end{array}$ & $\begin{array}{l}3.1 \% \\
\text { cour } \\
\text { he } m \\
\text { ount }\end{array}$ & $\begin{array}{r}\text { have } \\
\text { less } \\
\text { nimum } \\
.48 \text {. }\end{array}$ \\
\hline Interpretations & $\begin{array}{l}\text { From chi- } \\
\text { value is } \\
\text { rejects nul } \\
\text { H0. } \\
\text { and it } \\
\text { alternative } \\
\text { H1. }\end{array}$ & $\begin{array}{l}\text { iquar } \\
<0.0 \\
\text { l hyp } \\
\text { hyp }\end{array}$ & $\begin{array}{l}\text { test p } \\
\text { so it } \\
\text { thesis } \\
\text { the } \\
\text { thesis }\end{array}$ & $\begin{array}{l}\text { From chi } \\
\text { p value is } \\
\text { rejects } \\
\text { hypothes } \\
\text { and it } \\
\text { alternativ } \\
\text { hypothes }\end{array}$ & $\begin{array}{l}\text { i-squa } \\
\text { s }<0 . \\
\text { is H0 } \\
\text { accep } \\
\text { e } \\
\text { is H1. }\end{array}$ & $\begin{array}{l}5 \text { so it } \\
\text { null } \\
\text { s the }\end{array}$ & $\begin{array}{l}\text { From chi-s } \\
\text { value is } \\
\text { rejects nul } \\
\text { H0. } \\
\text { and it } \\
\text { alternative } \\
\text { H1. }\end{array}$ & $\begin{array}{l}\text { squar } \\
<0.05 \\
\text { l hyp } \\
\text { ccep } \\
\text { hyp }\end{array}$ & $\begin{array}{l}\text { test } p \\
\text { so it } \\
\text { thesis } \\
\text { s the } \\
\text { thesis }\end{array}$ & $\begin{array}{l}\text { From chi- } \\
\text { value is } \\
\text { rejects nu } \\
\text { H0. } \\
\text { and it } \\
\text { alternative } \\
\text { H1. }\end{array}$ & $\begin{array}{l}\text { squar } \\
<0.05 \\
\text { l hyp } \\
\text { accep } \\
\text { hyp }\end{array}$ & $\begin{array}{l}\text { test p } \\
\text { so it } \\
\text { othesis } \\
\text { s the } \\
\text { othesis }\end{array}$ \\
\hline
\end{tabular}




\section{To Study the Factors Affecting the Job Satisfaction and Level of Job Satisfaction at Baswara Garments Ltd}

\section{Hypothesis -5}

H0: Satisfaction level of Overall satisfaction is independent of demographic factors (Age , Gender, Category, Income level).

H1: Satisfaction level of Overall satisfaction is not independent of demographic factors (Age , Gender , Category, Income level).

Table -5 Pearson Chi -Square Test result and interpretation For Hypothesis -5

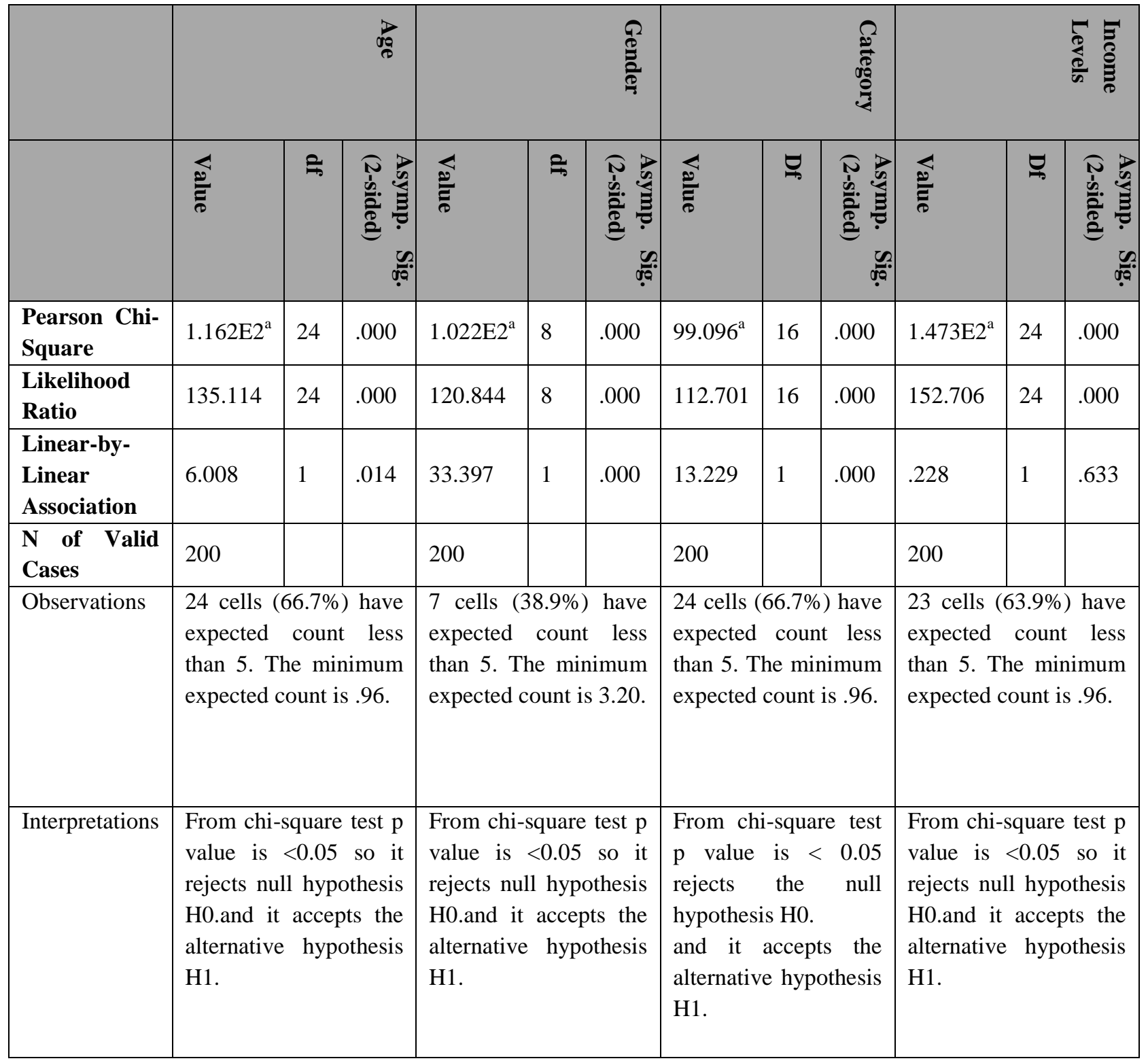


To measure the impact of each factor on overall job satisfaction of Employees

6. HO: Satisfaction level of workers have not significant impact on overall satisfaction.

H1: Satisfaction level of workers have significant impact on overall satisfaction

Table 6 Impact of each factor on overall job satisfaction

\begin{tabular}{|l|l|l|l|l|}
\hline \multirow{2}{*}{ Model } & $\begin{array}{l}\text { Unstandardized } \\
\text { Coefficients }\end{array}$ & $\begin{array}{l}\text { Standardized } \\
\text { Coefficients }\end{array}$ & t & Sig \\
\cline { 2 - 3 }$\beta$ & $\beta$ & Std. Error & & \\
\hline $1 \quad$ constant & -2.367 & .740 & -3.199 & .002 \\
Total WC & .138 & .033 & 4.231 & .000 \\
Total Pay & .159 & .030 & 5.296 & .000 \\
Total Promotion & .226 & .063 & 3.575 & .000 \\
Supervision & .146 & .042 & 3.468 & .001 \\
Gender & -.763 & .201 & -3.798 & .000 \\
Age & -.433 & .174 & -2.483 & .014 \\
Category & 1.725 & .217 & 7.964 & .000 \\
Income level & -1.419 & .179 & -7.918 & .000 \\
\hline
\end{tabular}

a. Dependent Variable: Overall Satisfaction

$\mathrm{Y}=\alpha+\beta \mathrm{x}$

Where $\mathrm{Y}=$ Overall satisfaction

$\alpha=$ Constant Intercept

$\beta=$ Slope

$\mathrm{Y}=\alpha+\beta \mathrm{WC}+\beta \mathrm{TP}+\beta \mathrm{TP}+\beta \mathrm{S}-\beta \mathrm{G}-\beta \mathrm{A}+\beta \mathrm{C}-\beta \mathrm{IL}$

Interpretation: From the above regression analysis we have conclude that the $\mathrm{p}$ value of total WC , Total Pay, Total promotion, Supervision, Gender, Age, Category, Income level is < 0.05 so it have significant impact on overall satisfaction. 
Table - 7 Correlations

\begin{tabular}{|c|c|c|c|c|c|c|c|c|c|c|}
\hline & & $\frac{9}{3}$ & 常 & 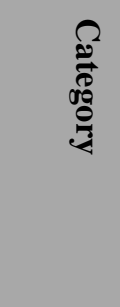 & 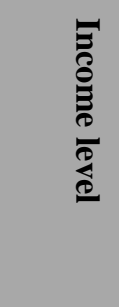 & 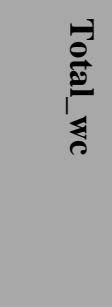 & & $\begin{array}{l}-1 \\
0 \\
0 \\
0 \\
0 \\
0 \\
0 \\
0 \\
0 \\
0 \\
0\end{array}$ & 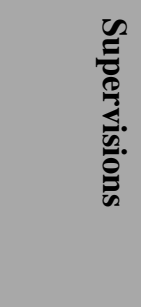 & 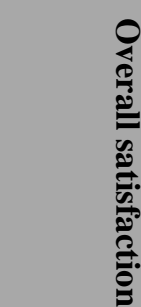 \\
\hline Gender & $\begin{array}{l}\text { Pearson } \\
\text { Correlation } \\
\text { Sig. (2- } \\
\text { tailed) } \\
\mathrm{N}\end{array}$ & $\begin{array}{l}1 \\
200\end{array}$ & $\begin{array}{l}.333^{* *} \\
.000 \\
200\end{array}$ & $\begin{array}{l}- \\
.234^{* *} \\
.001 \\
200\end{array}$ & $\begin{array}{l}-.147^{*} \\
.038 \\
200\end{array}$ & $\begin{array}{l}- \\
.237 * * \\
.001 \\
200\end{array}$ & $\begin{array}{l}-.322^{* *} \\
.000 \\
200\end{array}$ & $\begin{array}{l}-.156^{*} \\
.028 \\
200\end{array}$ & $\begin{array}{l}-.385^{* *} \\
.000 \\
200\end{array}$ & $\begin{array}{l}-.410^{* *} \\
.000 \\
200\end{array}$ \\
\hline Age & \begin{tabular}{l}
\multicolumn{2}{l}{ Pearson } \\
Correlation \\
Sig. (2- \\
tailed) \\
$\mathrm{N}$
\end{tabular} & $\begin{array}{l}.333^{* *} \\
.000 \\
200\end{array}$ & $\begin{array}{l}1 \\
200\end{array}$ & $\begin{array}{l}.006 \\
.930 \\
200\end{array}$ & $\begin{array}{l}.009 \\
.895 \\
200\end{array}$ & $\begin{array}{l}- \\
.291^{* *} \\
.000 \\
200 \\
.199 * *\end{array}$ & $\begin{array}{l}.198^{* *} \\
.005 \\
200\end{array}$ & $\begin{array}{l}-.097 \\
.170 \\
200\end{array}$ & $\begin{array}{l}.165^{*} \\
.019 \\
200\end{array}$ & $\begin{array}{l}.174^{*} \\
.014 \\
200\end{array}$ \\
\hline Category & \begin{tabular}{l}
\multicolumn{2}{l}{ Pearson } \\
Correlation \\
Sig. (2- \\
tailed) \\
$\mathrm{N}$
\end{tabular} & $\begin{array}{l}- \\
.234^{* *} \\
.001 \\
200\end{array}$ & $\begin{array}{l}.006 \\
.930 \\
200\end{array}$ & $\begin{array}{l}1 \\
200\end{array}$ & $\begin{array}{l}.827^{* *} \\
.000 \\
200\end{array}$ & $\begin{array}{l}.199^{* *} \\
.005 \\
200\end{array}$ & $\begin{array}{l}.154^{*} \\
.030 \\
200\end{array}$ & $\begin{array}{l}.059 \\
.408 \\
200\end{array}$ & $\begin{array}{l}.261^{* *} \\
.000 \\
200\end{array}$ & $\begin{array}{l}.258^{* *} \\
.000 \\
200\end{array}$ \\
\hline $\begin{array}{l}\text { Income } \\
\text { level }\end{array}$ & $\begin{array}{l}\text { Pearson } \\
\text { Correlation } \\
\text { Sig. (2- } \\
\text { tailed) } \\
\mathrm{N}\end{array}$ & $\begin{array}{l}.147^{*} \\
.038 \\
200\end{array}$ & $\begin{array}{l}.009 \\
.895 \\
200\end{array}$ & $\begin{array}{l}.827^{* *} \\
.000 \\
200\end{array}$ & $\begin{array}{l}1 \\
200\end{array}$ & $\begin{array}{l}.080 \\
.262 \\
200\end{array}$ & $\begin{array}{l}.018 \\
.798 \\
200\end{array}$ & $\begin{array}{l}-.128 \\
.070 \\
200\end{array}$ & $\begin{array}{l}.175^{*} \\
.013 \\
200\end{array}$ & $\begin{array}{l}-.034 \\
.000 \\
200\end{array}$ \\
\hline $\begin{array}{l}\text { Total } \\
\text { WC }\end{array}$ & \begin{tabular}{l}
\multicolumn{2}{l}{ Pearson } \\
Correlation \\
Sig. (2- \\
tailed) \\
$\mathrm{N}$ \\
\end{tabular} & $\begin{array}{l}- \\
.237^{* *} \\
.001 \\
200\end{array}$ & $\begin{array}{l}- \\
.291^{* *} \\
.000 \\
200\end{array}$ & $\begin{array}{l}.199 * * \\
.005 \\
200\end{array}$ & $\begin{array}{l}.080 \\
.262 \\
200\end{array}$ & $\begin{array}{l}1 \\
200\end{array}$ & $\begin{array}{l}.592^{* *} \\
.000 \\
200\end{array}$ & $\begin{array}{l}.526^{* *} \\
.000 \\
200\end{array}$ & $\begin{array}{l}.641^{* *} \\
.000 \\
200\end{array}$ & $\begin{array}{l}.658^{* *} \\
.000 \\
200\end{array}$ \\
\hline
\end{tabular}


Table 8 Correlation

\begin{tabular}{|c|c|c|c|c|c|c|c|c|c|c|}
\hline & & $\frac{8}{8}$ & $\underset{\substack{d a \\
d a}}{\vec{d}}$ & 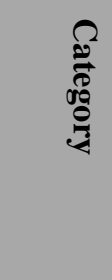 & 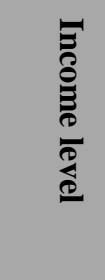 & 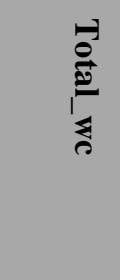 & & 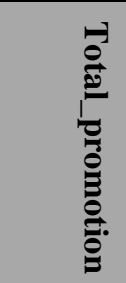 & 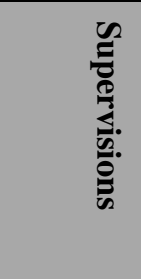 & 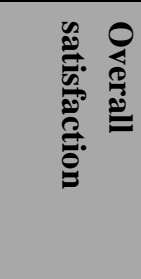 \\
\hline $\begin{array}{l}\text { Total } \\
\text { Pay }\end{array}$ & $\begin{array}{l}\text { Pearson } \\
\text { Correlation } \\
\text { Sig. (2- } \\
\text { tailed) } \\
\mathrm{N}\end{array}$ & $\begin{array}{l}- \\
.322^{* *} \\
.000 \\
200\end{array}$ & $\begin{array}{l}- \\
.198^{* *} \\
.005 \\
200\end{array}$ & $\begin{array}{l}.154^{*} \\
.030 \\
200\end{array}$ & $\begin{array}{l}.018 \\
.798 \\
200\end{array}$ & $\begin{array}{l}.592^{* *} \\
.000 \\
200\end{array}$ & $\begin{array}{l}1 \\
200\end{array}$ & $\begin{array}{l}.754^{* *} \\
.000 \\
200\end{array}$ & $\begin{array}{l}.690^{* *} \\
.000 \\
200\end{array}$ & $\begin{array}{l}.776^{* *} \\
.000 \\
200\end{array}$ \\
\hline $\begin{array}{l}\text { Total } \\
\text { promotion }\end{array}$ & $\begin{array}{l}\text { Pearson } \\
\text { Correlation } \\
\text { Sig. } \quad(2- \\
\text { tailed) } \\
\mathrm{N}\end{array}$ & $\begin{array}{l}-.156^{*} \\
.028 \\
200\end{array}$ & $\begin{array}{l}-.097 \\
.170 \\
200\end{array}$ & $\begin{array}{l}.059 \\
.408 \\
200\end{array}$ & $\begin{array}{l}.128 \\
.070 \\
200\end{array}$ & $\begin{array}{l}.526^{* *} \\
.000 \\
200\end{array}$ & $\begin{array}{l}.754^{* *} \\
.000 \\
200\end{array}$ & $\begin{array}{l}1 \\
200\end{array}$ & $\begin{array}{l}.614^{* *} \\
.000 \\
200\end{array}$ & $\begin{array}{l}.728^{* *} \\
.000 \\
200\end{array}$ \\
\hline Supervision & $\begin{array}{l}\text { Pearson } \\
\text { Correlation } \\
\text { Sig. (2- } \\
\text { tailed) } \\
\mathrm{N}\end{array}$ & $\begin{array}{l}- \\
.385^{* *} \\
.000 \\
200\end{array}$ & $\begin{array}{l}-.165^{*} \\
.019 \\
200\end{array}$ & $\begin{array}{l}.261^{* *} \\
.000 \\
200\end{array}$ & $\begin{array}{l}.175^{*} \\
.013 \\
200\end{array}$ & $\begin{array}{l}.641^{* *} \\
.000 \\
200\end{array}$ & $\begin{array}{l}.690^{* *} \\
.000 \\
200\end{array}$ & $\begin{array}{l}.614^{* *} \\
.000 \\
200\end{array}$ & $\begin{array}{l}1 \\
200\end{array}$ & $\begin{array}{l}.710^{* *} \\
.000 \\
200\end{array}$ \\
\hline $\begin{array}{l}\text { Overall } \\
\text { satisfaction }\end{array}$ & $\begin{array}{l}\text { Pearson } \\
\text { Correlation } \\
\text { Sig. (2- } \\
\text { tailed) } \\
\mathrm{N}\end{array}$ & $\begin{array}{l}- \\
.410^{* *} \\
.000 \\
200\end{array}$ & $\begin{array}{l}-.174^{*} \\
.014 \\
200\end{array}$ & $\begin{array}{l}.258^{* *} \\
.000 \\
200\end{array}$ & $\begin{array}{l}-.034 \\
.634 \\
200\end{array}$ & $\begin{array}{l}.658^{* *} \\
.000 \\
200\end{array}$ & $\begin{array}{l}.776^{* *} \\
.000 \\
200\end{array}$ & $\begin{array}{l}.728^{* *} \\
.000 \\
200\end{array}$ & $\begin{array}{l}.710^{* *} \\
.000 \\
200\end{array}$ & $\begin{array}{l}1 \\
200\end{array}$ \\
\hline
\end{tabular}

**. Correlation is significant at the 0.01 level (2-tailed).

* . Correlation is significant at the 0.05 level (2-tailed).

From regression analysis we have conclude that the p value of Total WC , Total Pay , Total Promotion , Supervision, age , category, gender and income level have significant impact on overall job satisfaction.

\section{FINDINGS AND CONCLUSION}

It has been concluded from the data analysis that, key factors affecting employees performance at Banswara Garments are working conditions, pay and related policies , performance and reward policies, promotion policies and training and development opportunities. Study reveals the fact that, at M/s BG, all the statutory and non-statutory measures are provided to employees as per the industry standards in India, which improves employee's satisfaction and increase productivity. Workers are mostly dissatisfied with the long working hours of the company. Workers do not have any dissatisfaction with respect to working conditions, performance reward 


\section{To Study the Factors Affecting the Job Satisfaction and Level of Job Satisfaction at Baswara Garments Ltd}

mechanism and developmental opportunities what company is providing as on the day. The other area of concern for them are the policies regarding bonus, leaves and insurance kind of rewards. Resistance towards the merit based promotion policy and poor on job trainings are other few areas where improvements can be done by the management.

\section{REFERENCES}

Ahamed F. (2014) Job Dissatisfaction In The Bangladesh Ready Made Garment Sector, International Journal of Business and Management review, Vol. 2, No. 1, March 2014.

Aziri B. (2011) “Job Satisfaction: A Literature Review Management Research And Practise” Vol. 3 Issuse 4 (2011) PP: 77-86.

Donald R.” Cooper Business Research Methods” Tata McGraw-Hill Publishing Company, 2012

Hettiararchchi H.A.. (2012) : "The effect of Employee Work Related Attitudes on Employee Job Performance: A Study of Tertiary and Vocational Education Sector in Sri Lanka.” IOSR Journal of Business and Management (IOSR-JBM) Volume 16, Issue 4. Ver. IV (Apr. 2014), PP 74-83.

Ikhtiar A. S. (2006) " Job Satisfaction of Female Workers in Different Garments Factories in Dhaka City: An Intertemporal Comparison ,” Daffodil International University Journal of Business and Economics, Vol.1, No. 1, 2006.

K. Aswathappa Human Resource And Personal Management, Tata McGraw-Hill,2005. M. Sari Lisa Human Resource Management, Winter 2004, Vol. 43, No. 4, Pp. 395-407.

Ken Black. Business Statistics, Willey India Edition. Reprint 2014

Khatun R.(2015) “Employee’s Views on Job Satisfaction : A Study on Garment Industry (AKH Group), Bangladesh International Journal of Research In Management and Business Studies, Vol. 2, No. 2, April 2015.

Kothari C..R “ Research Methodology Methods and Techniques”, Wishwa Prakashan, 2011

Kumari Geeta(2011) "Job Satisfaction in Public Sector and Private Sector: A Comparison International Journal of Innovation, Management and Technology”, Vol. 2, No. 3, June 2011.

Parvin M.(2011) "Factor Affecting Employee Job Satisfaction Of Pharmaceutical Sector" Australian Journal of Business and Management Research Vol.1No.9[113-123]

December-2011.

Sinha Ekta(2013) “ A Research Work On Employee Satisfaction Measurement With Special

Refrences To KRIBHCO, Surat, International Journal of Modern Engineering Research (IJMER) Vol.3, Issue.1, Jan-Feb. 2013 pp-523-529.

T Marwan, (2012) "The Shape Of The Relationship Between Salary And Job Satisfaction: A Field Study Far East Journal of Psychology and Business Vol 7 No.3 June 2012. 


\section{Websites}

http://www.search.ask.com/web?o=APN10371\&gct=SB\&q=www.Banswara\%20Syntex\%20ltd. Viewed On 18/06/2015.

http://www.search.ask.com/web?o=APN10371\&gct=SB\&q=\%EF\%83\%98\%09w

www.banswarasyntex.in.com.Viewed On Viewed On 18/06/2015.

How to cite this article: K Shukla, A Singh (2016), To Study the Factors Affecting the Job Satisfaction and Level of Job Satisfaction at Baswara Garments Ltd, International Journal of Indian Psychology, Volume 3, Issue 3, No. 9, DIP: 18.01.163/20160303, ISBN: 978-1-365$13820-1$ 